\title{
PENGETAHUAN DAN SIKAP BIDAN MENGENAI PENGGUNAAN PARTOGRAF DALAM PERSALINAN DI PUSKESMAS PONED KOTA MANADO
}

\author{
${ }^{1}$ Jacqueline P. Toemandoek \\ ${ }^{2}$ Freddy Wagey \\ ${ }^{2}$ Maria Loho
}

\author{
${ }^{1}$ Kandidat Skripsi Fakultas Kedokteran Universitas Sam Ratulangi Manado \\ ${ }^{2}$ Bagian Ilmu Obstetri dan Ginekologi Fakultas Kedokteran Universitas Samratulangi \\ Manado \\ Email:priscillatoemandoek@yahoo.com
}

\begin{abstract}
The high maternal mortality rate is mostly due to pregnancies and labours. Health workers who can help labour are inter alia midwives. A health center that has the facilities and the ability to provide 24-hours services to cope emergency cases of obstetric and neonatal care is called PONED Public Health Center (PHC). This study aimed to obtain the knowledge and attitude of midwives about partograph in PONED PHCs in Manado. There were 33 respondents of 6 PONED PHCs in Manado. The results showed that most of the midmives (90.9\%) in PONED PHCs had good knowledge about the usage of pantograph in labour; 2 respondents (6.1\%) had fair knowledge, and 1 respondent (3.0\%) had poor knowledge. All midwives (100\%) had positive attitude about the usage of partograph. Conclusion: Most midwives in PONED PHC in Manado had good knowledge and positive attitude about the usage of partograph in labour.
\end{abstract}

Keywords: midwives, PONED Public Health Center, partograph

\begin{abstract}
Abstrak: Tingginya angka kematian ibu terutama pada saat kehamilan dan persalinan. Tenaga kesehatan yang dapat menolong persalinan yaitu salah satunya bidan. Puskesmas yang memiliki fasilitas dan kemampuan memberikan pelayanan untuk menanggulangi kasus kegawatdaruratan obstetrik dan neonatal selama 24 jam yaitu puskesmas PONED. Pada penelitian ini terdapat 33 responden dari 6 puskesmas PONED di Kota Manado. Hasil penelitian memperlihatkan bahwa tingkat pengetahuan bidan tentang penggunaan partograf dalam persalinan di Puskesmas PONED Kota Manado umumnya $(90,9 \%)$ baik, 2 responden (6,1\%) cukup, dan 1 responden (3,0\%) kurang. Mengenai distribusi sikap, semua bidan (100\%) mempunyai sikap positif. Simpulan: Umumnya bidan di puskesmas PONED Kota Manado mempunyai pengetahuan yang baik dan sikap yang positif mengenai penggunaan partograf dalam persalinan.
\end{abstract}

Kata kunci: bidan, puskesmas PONED, partograf

Pada tahun 2010 terdapat 67 ibu yang meninggal dari 36.503 kelahiran hidup. Angka Kematian Ibu (AKI) merupakan salah satu indikator untuk melihat derajat kesehatan perempuan. Untuk menurunkan AKI harus dilakukan secara efektif agar mencapai target yang sesuai dengan harapan. Salah satu faktor penting dalam penurunan angka kematian tersebut ialah penyediaan pelayanan kesehatan maternal dan perinatal yang berkualitas dengan tenaga kesehatan yang trampil didukung oleh sarana dan prasarana yang memadai. ${ }^{2}$ Tenaga kesehatan yang dapat 
menolong persalinan salah satunya ialah bidan. Bidan adalah seseorang yang telah menjalani program pendidikan bidan, yang diakui oleh negara tempat ia tinggal, dan telah berhasil menyelesaikan studi terkait kebidanan serta memenuhi persyaratan untuk terdaftar dan/atau memiliki izin formal untuk praktik bidan. ${ }^{2}$

Salah satu kompetensi Bidan yang harus di penuhi oleh Bidan adalah memberikan asuhan kebidanan yang bermutu, tanggap terhadap kebudayaan selama persalinan, memimpin suatu persalinan yang bersih dan aman serta menguasai situasi kegawadaruratan untuk mengoptimalkan kesehatan wanita dan bayi baru lahir. ${ }^{3}$

Puskesmas PONED (Pelayanan Obstetric-Neonatal Emergency Dasar) adalah puskesmas yang memiliki fasilitas dan kemampuan memberikan pelayanan untuk menanggulangi kasus kegawatdaruratan obstetrik dan neonatal selama 24 jam. Sebuah Puskesmas PONED harus memenuhi standar yang meliputi standar administrasi dan manajemen, fasilitas bangunan atau ruangan, peralatan dan obatobatan, tenaga kesehatan dan fasilitas penunjang lain. ${ }^{4}$

Puskesmas PONED juga harus mampu memberikan pelayanan yang meliputi penanganan preeklampsi, eklampsi, perdarahan, sepsis, sepsis neonatorum, asfiksia, kejang, ikterus, hipoglikemia, hipotermi, tetanus neonatorum, trauma lahir, Berat Badan Lahir Rendah (BBLR), sindroma gangguan pernapasan dan kelainan kongenital. ${ }^{4}$

Partograf dapat digunakan untuk mendeteksi dini masalah dan penyulit dalam persalinan seperti partus lama, perdarahan dan gawat janin, sehingga dapat sesegera mungkin mengambil tindakan atau merujuk ibu dalam kondisi optimal. ${ }^{5}$

Menurut WHO (1994) partograf merupakan suatu cara yang tepat untuk memantau keadaan ibu dan janin selama dalam persalinan. Partograf standar WHO dapat membedakan dengan jelas perlu atau tidaknya intervensi dalam persalinan. Juga dapat dengan jelas membedakan persalinan normal dan abnormal dan mengidentifikasi wanita yang membutuhkan intervensi. ${ }^{6}$

Partograf digunakan antara lain untuk:

1. Mencatat hasil observasi dan kemajuan persalinan dengan menilai pembukaan serviks melalui pemeriksaan dalam

2. Mendeteksi apakah proses persalinan berjalan secara normal, sehingga dapat melakukan deteksi secara dini terhadap setiap kemungkinan terjadinya partus lama. Dengan metode yang baik dapat diketahui lebih awal adanya persalinan yang abnormal dan dapat dicegah persalinan lama, sehingga dapat menurunkan resiko perdarahan pospartum dan sepsis, mencegah persalinan macet, pecah rahim, dan infeksi bayi baru lahir.7

Penggunaan partograf harus digunakan secara rutin oleh semua penolong persalinan yang memberikan asuhan persalinan kepada ibu dan proses kelahiran bayinya (Spesialis Obstetri, bidan, dokter umum, residen, dan mahasiswa kedokteran). ${ }^{8}$

\section{METODE PENELITIAN}

Penelitian ini menggunakan rancangan potong lintang. Penelitian dilaksanakan terhadap bidan yang ada dan bekerja di Puskesmas PONED yaitu; Puskesmas Bahu, Puskesamas Tuminting, Puskesmas Wawonasa, Puskesmas Paniki, Puskesmas Ranotana, dan Puskesmas Kombos di Kota Manado. Sampel penelitian ialah seluruh populasi yang ada. Teknik pengambilan sampel menggunakan total sampling. Variabel penelitian ini ialah:

- Variabel bebas: Pengetahuan, sikap, dan bidan Puskesmas PONED mengenai partograf.

- Variabel terikat: Umur, pendidikan, dan Lama Kerja.

Data penelitian diperoleh melalui kuisoner yang merupakan modifikasi dari beberapa kuesioner penelian sebelumnya. Data terdiri dari dua bagian. Bagian pertama berisi tentang pengetahuan 
sedangkan bagian kedua tentang sikap. Cara penilaian skoring kuesioner menggunakan skala Guttman dimana setiap pertanyaan dengan jawaban benar nilainya $=1$ dan pertanyaan dengan jawaban salah nilainya $=0$. Terdapat 15 pertanyaan dengan penilaian mengidentifikasi hasil skor pengetahuan yang dibagi menjadi 3 kategori penilaian yaitu:

1. Baik bila diperoleh jawaban benar 76$100 \%$

2. Cukup bila diperoleh jawaban benar 56$75 \%$

3. Kurang bila diperoleh jawaban benar $<56 \%$

Sikap dalam penelitian ini diukur dengan skala Likert yang dapat dipergunakan untuk mengukur sikap, pendapat, dan persepsi seseorang atau sekelompok orang tentang suatu gejala. Terdapat 2 bentuk pertanyaan yang menggunakan skala ini yaitu bentuk pertanyaan positif untuk mengukur sikap positif, dan bentuk pertanyaan negatif untuk mengukur sikap negatif. Pertanyaan positif diberi skor 3,2, dan 1, sedangkan bentuk pertanyaan negatif diberi skor 1,2, dan 3. Bentuk jawaban skala Likert ialah Setuju (S), Ragu-Ragu (RR), dan Tidak Setuju (TS). Jumlah pertanyaan sikap yaitu sebanyak 10 pertanyaan.

\section{HASIL PENELITIAN}

Distribusi usia pada Tabel 1 disusun berdasarkan kriteria usia Departemen Kesehatan Republik Indonesia (Depkes RI) tahun 2009. Masa remaja akhir (17-25 tahun), masa dewasa awal (26-35 tahun), masa dewasa akhir (36-45 tahun), dan masa lansia awal (46-55 tahun). Tabel 1 menunjukkan responden terbanyak ialah masa dewasa awal (26-35 tahun).

Tabel 1. Distribusi berdasarkan karakteristik umur

\begin{tabular}{ccc}
\hline Umur & $\mathrm{n}$ & $\%$ \\
\hline $17-25$ & 6 & 18,2 \\
$26-35$ & 22 & 66,7 \\
$36-45$ & 4 & 12,1 \\
$46-55$ & 1 & 3,0 \\
\hline Total & 33 & 100,0 \\
\hline
\end{tabular}

Dari Tabel 2 dilihat bahwa responden terbanyak yaitu bidan yang berpendidikan D3, 75,8\% dari total 33 responden.

Tabel 2. Distribusi berdasarkan karakteristik pendidikan

\begin{tabular}{ccc}
\hline Pendidikan & $\mathrm{n}$ & $\%$ \\
\hline D3 & 25 & 75,8 \\
D4 & 5 & 15,2 \\
S1 & 3 & 9,1 \\
\hline Total & 33 & 100,0 \\
\hline
\end{tabular}

Tabel 3 menunjukkan lama kerja bidan puskesmas yang terbanyak yaitu 1-5 tahun sebesar $51,5 \%$.

Tabel 3. Distribusi berdasarkan karakteristik lama kerja

\begin{tabular}{ccc}
\hline Lama Kerja & $\mathrm{n}$ & $\%$ \\
\hline $1-5$ & 17 & 51,5 \\
$6-10$ & 9 & 27,3 \\
$>10$ & 7 & 21,2 \\
\hline Total & 33 & 100,0 \\
\hline
\end{tabular}

Tabel 4. Distirbusi berdasarkan tingkat Pengetahuan di masing-masing puskesmas

\begin{tabular}{|c|c|c|c|c|c|c|}
\hline \multirow[t]{3}{*}{ Puskesmas } & \multicolumn{6}{|c|}{ Pengetahuan } \\
\hline & \multicolumn{2}{|c|}{ Kurang } & \multicolumn{2}{|c|}{ Cukup } & \multicolumn{2}{|c|}{ Baik } \\
\hline & $\mathrm{n}$ & $\%$ & $\mathrm{n}$ & $\%$ & $\mathrm{n}$ & $\%$ \\
\hline Paniki & - & - & - & - & 9 & 100 \\
\hline Bahu & - & - & - & - & 6 & 100 \\
\hline Tuminting & - & - & 1 & 25 & 3 & 75 \\
\hline Kombos & - & - & 1 & 17 & 5 & 83 \\
\hline Wawonasa & - & - & - & - & 7 & 100 \\
\hline Ranotana Weru & 1 & 100 & - & - & - & - \\
\hline
\end{tabular}


Tabel 4 memperlihatkan puskesmas yang menjadi tempat penelitian dan tingkat pengetahuan responden. Terdapat 33 responden yang mengisi kuesioner dengan benar. Semua bidan di Puskesmas Paniki, Bahu, dan Wawonasa bidan menjawab dengan hasil baik 100\% sedangkan di Puskesmas Tuminting dan Kombos sebagian besar bidan menjawab dengan hasil baik (75\% dan 83\%).

Tabel 5 menunjukkan bahwa semua pasien dari Puskesmas Paniki, Bahu, Tuminting, Kombos, Wawonasa, dan Ranotana Weru mempunyai sikap positif.

Tabel 5. Distribusi berdasarkan sikap di masing-masing puskesmas

\begin{tabular}{lcccc}
\hline \multirow{2}{*}{ Puskesmas } & \multicolumn{4}{c}{ Sikap } \\
\cline { 2 - 5 } & \multicolumn{2}{c}{ Negatif } & \multicolumn{2}{c}{ Positif } \\
Paniki & $\mathrm{n}$ & $\%$ & $\mathrm{n}$ & $\%$ \\
Bahu & - & - & 9 & 100 \\
Tuminting & - & - & 6 & 100 \\
Kombos & - & - & 4 & 100 \\
Wawonasa & - & - & 6 & 100 \\
Ranotana Weru & - & - & 7 & 100 \\
\hline
\end{tabular}

\section{BAHASAN}

Tabel 1 menunjukkan bahwa golongan umur terbanyak dari 33 responden yaitu 2635 tahun sebanyak 22 responden, sedangkan umur 17-25 tahun 6 responden, umur 36-45 tahun 4 responden, dan umur 46-55 tahun 1 responden. Menurut Nursalam dan Siti, semakin cukup umur tingkat kematangan dan kekuatan seseorang akan lebih matang dalam berfikir dan bekerja. ${ }^{9}$

Berdasarkan Tabel 2 dapat dilihat bahwa distribusi responden yang terbanyak berdasarkan pendidikan yaitu D3 sebanyak 25 responden (75,8\%), diikuti D4 sebanyak 5 responden (15,2\%), dan yang terendah yaitu berpendidikan S1 sebanyak 3 responden (9,1\%). Menurut Notoatmodjo, pendidikan adalah upaya untuk memberikan pengetahuan sehingga terjadi perubahan perilaku positif yang meningkat. Setiap individu umumnya menginginkan pendidikan, dan makin banyak serta makin tinggi pendidikan sesorang maka makin baik tingkat pengetahuan yang dimilikinya. ${ }^{10}$ Responden terbanyak yaitu bidan yang berpendidikan D3 yaitu program pendidikan tinggi kebidanan yang mempersiapkan peserta didik untuk memiliki kemampuan dalam melaksanakan pekerjaan yang bersifat rutin, maupun tidak rutin secara mandiri dalam pelaksanaan tanggung jawab pekerjaannya, serta mampu melakukan pengawasan serta bimbingan atas dasar keterampilan manajerial yang dimilikinya. ${ }^{11}$

Berdasarkan Tabel 3 dapat dilihat bahwa distribusi responden berdasarkan karakteristik lama kerja bidan yang terbanyak yaitu 1-5 tahun sebanyak 17 responden (41,5\%). Menurut Azwar, sesuatu yang pernah dilakukan seseorang dapat menambah pengetahuan tentang sesuatu yang bersifat non formal. Pengalaman secara langsung berhubungan dengan peningkatan pengetahuan, makin banyak pengalaman yang ditemui dalam hidup maka akan memberi pengaruh langsung pada pengetahuan seseorang. Seorang bidan yang sering menolong pasien dan melakukan pengisian partograf akan memengaruhi pengetahuan dan sikapnya secara langsung. ${ }^{12}$

Dari hasil data penelitian yang didapatkan pengetahuan responden baik yaitu 30 responden (90,9\%) dari 33 responden, pengetahuan cukup yaitu 2 responden (6,1\%), dan pengetahuan kurang yaitu 1 responden (3,0\%). Untuk melakukan pengisian partograf, bidan harus mengerti dulu tujuan partograf, yaitu alat bantu untuk memantau kemajuan kala satu atau persalinan dan informasi keputusan klinik. Dari penelitian ini semua bidan dapat menjawab dengan benar mengenai tujuan partograf. ${ }^{7}$

Partograf terdiri dari 3 komponen yaitu: catatan janin, catatan kemajuan persalinan dan catatan ibu dan dapat dianggap sebagai "sistim peringatan awal", yang akan membantu pengambilan keputusan lebih awal kapan seorang ibu harus dirujuk, dipercepat atau diakhiri persalinannya. ${ }^{13}$ 
JHPIEGO membuat penelitan pada bidan di Ghana yang sudah selesai 2 tahun sekolah. Pada variabel pengetahuan mengenai partograf ada 14 pertanyaan, untuk menilai pengetahuan digunakan 2 penilaian intervensi dan kontrol. Karena ada beberapa ketidakseimbangan antara kelompok dalam hal usia, beberapa tahun pada pekerjaan, dan tingkat pelatihan sebelum sekolah kebidanan, analisis pada masing-masing sub-skala keterampilan yang kembali menjalankan dengan variabel ini sebagai kovariat. Serupa dengan pengetahuan skala ANCOVA itu, pola perbedaan antara kedua kelompok tetap sama setelah kovariat dimasukkan. Bidan pada kelompok intervensi memiliki skor penilaian keterampilan yang lebih tinggi secara keseluruhan dibandingkan kelompok kontrol. ${ }^{14}$ Hasil yang didapatkan pada penelitian di Ghana menunjukkan pengetahuannya baik sehingga pendekatan pelatihan ini harus diadopsi oleh bidang teknis lainnya atau kader lainnya, dan diterapkan untuk lembaga pendidikan pra layanan lain di wilayah ini. ${ }^{14}$

Hasil penelitian yang dilakukan Ernawati ${ }^{13}$ pada bidan tentang penggunaan partograf dalam persalinan di Puskesmas Papar menunjukkan bahwa 14 responden (77,8\%) berpengetahuan baik dan 4 responden $(22,2 \%)$ berpengetahuan cukup. Berdasarkan data survei demografi angka kematian ibu mencapai 334 per 100.000 kelahiran hidup setiap tahunnya. Penyebab kematian tersebut salah satunya kelemahan dalam hal sistem rujukan. ${ }^{15}$

Kewajiban membuat partograf sebagai kebutuhan atau merupakan satu paket dalam proses pertolongan persalinan. Keberadaan partograf itu wajib dibuat sebagai salah satu kebutuhan yang harus ada dalam proses pertolongan persalinan. Temuan-temuan yang ada selama proses persalinan harus dicatat dalam partograf. Penggunaan partograf diperlukan untuk pengambilan keputusan klinis dan deteksi dini komplikasi dalam pertolongan persalinan, seperti misalnya partus lama. ${ }^{13}$

Terdapat beberapa faktor yang memengaruhi pencapaian sikap antara lain faktor kemampuan (ability) dan faktor motivasi (motivation). Faktor motivasi merupakan suatu sikap seseorang terhadap situasi kerja dilingkungan organisasinya. Mereka yang bersikap positif terhadap situasi kerjanya akan menunjukkan motivasi kerja tinggi dan sebaliknya jika mereka bersikap negatif terhadap situasi kerjanya akan menunjuk motivasi kerja yang rendah. Situasi kerja yang dimaksud seperti hubungan kerja, fasilitas kerja, iklim kerja, kebijakan dan pimpinan. ${ }^{16}$

JHPIEGO juga meneliti pembagian kelompok intervensi dan kontrol. Kinerja kelompok pada sikap bidan sama bedanya dengan pengetahuan. Kelompok interversi lebih baik daripada kelompok kontrol di beberapa daerah. Pada kelompok interversi hasil baik pada sikap: mencuci tangan, dekontaminasi alat, penggunaan sarung tangan. ${ }^{14}$

Penelitian Ernawati ${ }^{13}$ berdasarkan analisis data terdapat 6 bidan (33,3\%) menerapkan partograf dalam persalinan dan 12 bidan (66,7\%) tidak menerapkan partograf dalam persalinan. Hal ini disebabkan karena pengetahuan bidan yang baik $(77,8 \%)$ tentang partograf itu sendiri dan juga telah disebutkan bahwa perilaku yang didasari oleh pengetahuan walaupun masih ada 12 responden tidak menerapkan partograf selama persalinan. Hal ini dipengaruhi kebiasaan bidan itu sendiri yang selalu menggunakannya setelah persalinan selesai atau disebabkan kurangnya kesadaran tentang pentingnya partograf dalam persalinan. Seperti yang telah disebutkan bahwa perilaku yang tidak didasari oleh kesadaran tidak akan berlangsung lama. ${ }^{15}$

Kinerja bidan sangat dipengaruhi oleh faktor internal maupun eksternal. Kinerja mengandung komponen kompetensi dan produktifvtas hasil sehingga sangat tergantung pada tingkat kemampuan individu dalam pencapaian hasil. ${ }^{17}$

\section{SIMPULAN}

Umumnya bidan di puskesmas PONED Kota Manado mempunyai pengetahuan yang baik dan sikap yang 
Toemadoek, Wagey, Loho: Pengetahuan dan sikap bidan mengenai penggunaan ...

positif mengenai penggunaan partograf dalam persalinan.

\section{SARAN}

Penerapan partograf diharapkan dapat menurunkan risiko terjadinya komplikasi pada ibu dan bayi. Kualitas sumber daya bidan harus ditingkatkan karena hal ini sangat menentukan tingkat keberhasilan pelayanan suatu organisasi pelayanan kesehatan.

\section{DAFTAR PUSTAKA}

1. World Health Organization. Reduction of Maternal Mortality: a joint WHO/UNFPA/UNICEF/World Bank Statement. Publication of the World Health Organization: Geneva, 1999.

2. Kementerian Kesehatan Republik Indonesia. [cited 2011 Jun 11]. Petunjuk Teknis Jaminan Persalinan. Jakarta, 2011.

3. Dinkes Kota Manado, 2010/2011. Laporan Bulanan Gizi. Manado.

4. Bosse G, Massawe S, Jann A. The Partograph in Daily Practice: It's quality that Matters. 2002. International Journal of Gynecology\&obstetric. Available at http://www.elsevier.com/locate/ijgo. 77, 243-244.

5. Budijanto D. Upaya Peningkatan Ketrampilan Manajemen Bidan dalam Pertolongan Persalinan dan Pasca Persalinan di Rumah dan Fasilitas Kesehatan. 2006. [cited 2009 Dec 16]. Available from: http://www.litbang.depkes.go.id.

Partograf alat pemantau persalinan http://www.indonesianpublichealth.com/2014/05/partografalat-pemantauan-persalinan.html (di akses pada 11-8-2014)

6. Partograf alat pemantau persalinan. [cited 2014 Aug 11]. Available from: http://www.indonesianpublichealth.com/2014/05/partografalat-pemantauan-persalinan.html.

7. Pelatihan Klinik asuhan persalinan normal, jaringan nasional pelatihan klinik- kesehatan reproduksi. Jakarta: Departemen Kesehatan Republik Indonesia, 2008.

8. Kepmenkes RI Nomor 369/Menkes/SK/III/2007. Tentang Standar Profesi Bidan. 2007. Available from: http://www.puspronakesln.org/pdfuploa d/ KMKNo.369ttgSPBidan.pdf

9. Notoatmodjo S. Pendidikan Kesehatan dan Ilmu perilaku. Jakarta: Rineka Cipta, 2003.

10. Standar nasional pendidikan diploma 3 kebidanan Indonesia, IBI (Ikatan Bidan Indonesia), AIPKIND (Asosiasi Institusi Pendidikan Kebidanan Indonesia). Jakarta, 2012.

11. Azwar A. Pelayanan Kesehatan. Jakarta: Yayasan Pustaka Utama, 2005.

12. Sulistyaningsih I. Studi korelasi tingkat pengetahuan dan bidan praktik swasta di kota Yogyakarta kelengkapan partograf dan kewewenangannya memaparkan isi rekam, 2007.

13. Ernawati E. Gambaran pengetahuan dan penerapan bidan menggunakan partograf dalam persalinan. [cited 2013 Nov 14]. Available from: http://www.scribd.com/doc/184047734/ gambaran-pengetahuan-dan-penerapanbidan-menggunakan-partograf-dalampersalinan-pdf\#scribd.

14. Notoadmodjo S. Promosi Kesehatan dan Ilmu Perilaku. Jakarta, Rineka cipta, 2007.

15. Laporan Pencapaian Tujuan Pembangunan Milenium Di Indonesia. Kementerian Perencanaan Pembangunan Nasional /Badan Perencanaan Pembangunan Nasional (BAPPENAS). Jakarta, 2010.

16. StatisticsIndonesia. [cited 2014 Oct 27]. Available from: http://www.datastatistiindonesia.com/portal/index.php?option =com_content\&task=view\&id=450\&Ite mid $=450 \&$ limit $=1 \&$ limitstart $=1$.

17. Peran dan fungsi bidan. [cited 2011 May 28]. Available from: http://infobidannia.wordpress.com/2011 /05/28/peran-dan-fungsi-bidan/ 